\title{
TU/e EmonONEN

\section{An easily coatable temperature responsive cholesteric liquid crystal oligomer for making structural colour patterns}

\section{Citation for published version (APA):}

Zhang, P., Kragt, A. J. J., Schenning, A. P. H. J., de Haan, L. T., \& Zhou, G. (2018). An easily coatable temperature responsive cholesteric liquid crystal oligomer for making structural colour patterns. Journal of Materials Chemistry C, 6(27), 7184-7187. https://doi.org/10.1039/c8tc02252f

\section{Document license:}

TAVERNE

DOI:

10.1039/c8tc02252f

Document status and date:

Published: 21/07/2018

\section{Document Version:}

Publisher's PDF, also known as Version of Record (includes final page, issue and volume numbers)

\section{Please check the document version of this publication:}

- A submitted manuscript is the version of the article upon submission and before peer-review. There can be important differences between the submitted version and the official published version of record. People interested in the research are advised to contact the author for the final version of the publication, or visit the $\mathrm{DOI}$ to the publisher's website.

- The final author version and the galley proof are versions of the publication after peer review.

- The final published version features the final layout of the paper including the volume, issue and page numbers.

Link to publication

\section{General rights}

Copyright and moral rights for the publications made accessible in the public portal are retained by the authors and/or other copyright owners and it is a condition of accessing publications that users recognise and abide by the legal requirements associated with these rights.

- Users may download and print one copy of any publication from the public portal for the purpose of private study or research.

- You may not further distribute the material or use it for any profit-making activity or commercial gain

- You may freely distribute the URL identifying the publication in the public portal.

If the publication is distributed under the terms of Article 25fa of the Dutch Copyright Act, indicated by the "Taverne" license above, please follow below link for the End User Agreement:

www.tue.nl/taverne

Take down policy

If you believe that this document breaches copyright please contact us at:

openaccess@tue.nl

providing details and we will investigate your claim. 
Check for updates

Cite this: J. Mater. Chem. C, 2018,

6. 7184

Received 9th May 2018,

Accepted 25th June 2018

DOI: $10.1039 / c 8 t c 02252 f$

rsc.li/materials-c

\section{An easily coatable temperature responsive cholesteric liquid crystal oligomer for making structural colour patterns $\dagger$}

\author{
Pei Zhang, ${ }^{a}$ Augustinus J. J. Kragt, (D) ${ }^{b}$ Albertus P. H. J. Schenning, (D) ${ }^{b}$ \\ Laurens T. de Haan (D)*a and Guofu Zhou*ac
}

\begin{abstract}
A crosslinkable cholesteric main-chain liquid crystal oligomer was prepared, and coated on glass using blade-coating. The coating showed a reflection band that varied as a function of temperature over a range of several hundreds of nanometers. This allowed patterning of the coating in various colours using multiple crosslinking steps at different temperatures.
\end{abstract}

Nature is full of colourful surfaces produced by photonic structures, ${ }^{1-3}$ such as the feathers of birds, the wings of butterflies, and the exoskeleton of beetles. Inspired by this, scientists have developed structured photonic materials with coloured patterns, which have potential applications including anti-counterfeit labels, sensors, and decorative elements; using techniques such as inkjet printing, ${ }^{4-6}$ selective immobilization and/or modification with UV irradiation or oxygen plasma, ${ }^{7-13}$ and patterned substrate-induced assembly. ${ }^{14-16}$ Cholesteric (chiral nematic) liquid crystals (LCs) are particularly interesting materials for photonic surfaces, as they have a helical structure that acts as a Bragg reflector with a reflection peak that depends on both the cholesteric pitch, which is the distance over which the molecular director makes one full rotation, and the average refractive index. Such a phase arises when a chiral dopant is added to a nematic LC mixture. ${ }^{17}$ The cholesteric pitch length can be altered by temperature, which allows for the preparation of temperature-responsive photonics. ${ }^{18-26}$ Coloured photonic CLC coatings can be prepared by inkjet printing or blade-coating. ${ }^{27-29}$ However, to make patterned cholesteric coatings commercially viable on a large scale, a preparation technique is needed which relies on a

\footnotetext{
${ }^{a}$ SCNU-TUE Joint Lab of Device Integrated Responsive Materials (DIRM), National Center for International Research on Green Optoelectronics, South China Normal University, Guangzhou 510006, P. R. China. E-mail: ldhaan@guohua-oet.com, guofu.zhou@m.scnu.edu.cn

${ }^{b}$ Stimuli-responsive Functional Materials and Devices, Department of Chemical Engineering and Chemistry, Eindhoven University of Technology, Den Dolech 2, $5600 \mathrm{MB}$ Eindhoven, The Netherlands

'Shenzhen Guohua Optoelectronics Tech. Co. Ltd, Shenzhen, 518110, P. R. China $\dagger$ Electronic supplementary information (ESI) available. See DOI: 10.1039/ c8tc02252f
}

combination simple and flexible chemistry and straightforward patterning steps. Currently, such a process has not been reported.

Recently, an elegant new way was reported to prepare main-chain liquid crystal oligomers, which involved the main-chain polymerization of diacrylate liquid crystal molecules and a chain extender, such as butylamine ${ }^{30}$ (Fig. S1, ESI $\dagger$ ) or a dithiol ${ }^{31,32}$ at elevated temperature. These crosslinkable nematic liquid crystal oligomers were used to make temperature-responsive actuators in a cell and through $3 \mathrm{D}$ printing. ${ }^{30,31,33,34}$ However, a cholesteric version of this oligomer has never been prepared.

Here, we report on a simple and versatile method for preparing temperature-responsive reflective coatings based on a cross-linkable cholesteric main-chain LC oligomer by blade-coating. An IRreflective coating showed a $500 \mathrm{~nm}$ blue shift upon heating, while visible coloured coatings showed a $300 \mathrm{~nm}$ blue shift. In the latter case, using multiple crosslinking steps at different temperatures, stable full colour patterns could be obtained.

The crosslinkable main-chain cholesteric LC oligomer was prepared by mixing diacrylate LC monomer 1 and right-handed chiral diacrylate monomer 2 (10.6 wt\%) with butylamine (Fig. 1). The mixture was dissolved in dichloromethane (DCM) in a vial and magnetically stirred at room temperature for 24 hours, leading to the formation of secondary amines. The DCM was evaporated while stirring at $100{ }^{\circ} \mathrm{C}$ and THF was added instead. The mixture was stirred at $100{ }^{\circ} \mathrm{C}$ for 18 hours to finish the oligomerization through the formation of tertiary amines. The vial was put in a vacuum oven at $50{ }^{\circ} \mathrm{C}$ overnight to remove the remaining THF. The product was a viscous material that no longer crystalized at room temperature, indicating the formation of an oligomer. This was confirmed by DSC measurements, which showed a glass transition temperature instead of a crystallization point at $-24{ }^{\circ} \mathrm{C}$ (Fig. S2, ESI $\dagger$ ). The oligomer had a wide liquid crystal window ranging from $-24{ }^{\circ} \mathrm{C}$ to $70{ }^{\circ} \mathrm{C}$. ${ }^{1} \mathrm{H}-\mathrm{NMR}$ measurements showed that the average degree of oligomerization was 2.6, as calculated from the ratio between the aromatic methyl group and the acrylate end group (Fig. S3, ESI $\dagger$ ). The oligomer had only acrylate end groups, as no secondary amines were detected. 


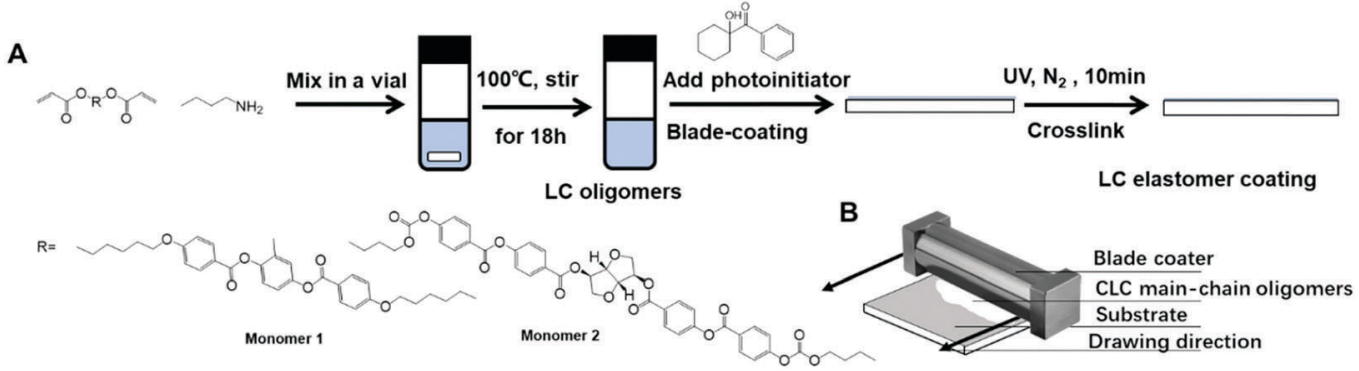

Fig. 1 Schematic representation of the coating process. (A) The fabrication of cholesteric liquid crystalline polymer network coating. (B) The bladecoating procedure.

$1 \mathrm{wt} \%$ photoinitiator (Irgacure 184) was added to the oligomer to allow crosslinking of the remaining acrylate groups with UV light; $1 \mathrm{wt} \%$ surfactant (2-( $N$-ethylperfluorooctanesulfonamido)ethyl methacrylate) was added to help with the alignment at the coating-air interface, and $20 \mathrm{wt} \%$ THF was added to decrease the viscosity. The mixture was then applied to a glass substrate with a rubbed poly(vinyl alcohol) (PVA) alignment layer at $50{ }^{\circ} \mathrm{C}$ using a blade coater. The gap used was $10 \mu \mathrm{m}$, and the coating speed was $15 \mathrm{~mm} \mathrm{~s}^{-1}$. The THF was then evaporated on a hot plate for at least 30 minutes at $50{ }^{\circ} \mathrm{C}$. Upon cooling to room temperature the resulting photonic coating had a reflection band at $1195 \mathrm{~nm}$ (Fig. 2A) and was highly stable, showing no de-wetting, crystallization, or evaporation even after 1.5 months at room temperature (Fig. S5, ESI $\dagger$ ). The helical twisting power of the chiral dopant is significantly lower compared to previously reported values, ${ }^{35}$ which most likely is the consequence of the oligomerization step.

The temperature response of the coating before crosslinking was studied using UV-VIS-NIR spectroscopy (Fig. 2A). When
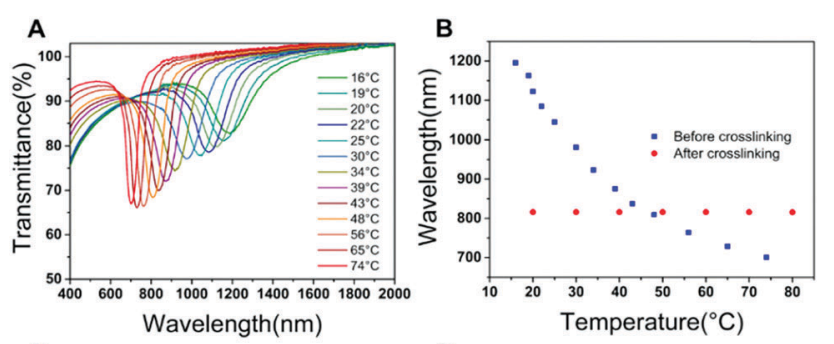

C
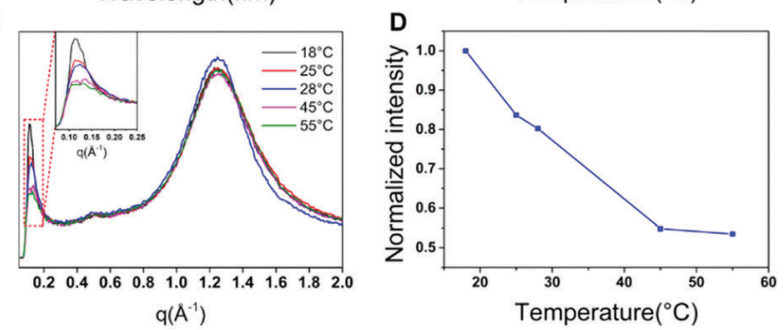

Fig. 2 (A) Transmittance spectra of the cholesteric LC coating before crosslinking, upon heating from $16^{\circ} \mathrm{C}$ to $74{ }^{\circ} \mathrm{C}$. (B) Reflection wavelength versus temperature of the coating before and after crosslinking at $50{ }^{\circ} \mathrm{C}$. (C) WAXS of the coatings cured at different temperatures. The inset highlights the peak caused by the presence of smectic order $\left(q=0.11 \AA^{-1}\right.$ ). (D) Normalized scattering intensities of the $q=0.11 \AA^{-1}$ peak for different curing temperatures heated from $16{ }^{\circ} \mathrm{C}$ to $74{ }^{\circ} \mathrm{C}$, the reflection band underwent a $496 \mathrm{~nm}$ blue shift from $1195 \mathrm{~nm}$ to $701 \mathrm{~nm}$. To determine whether the temperature response is a property that emerges from the oligomerization process, a coating was prepared based on the mixture of monomer $\mathbf{1}$ and monomer 2 by applying the mixture on a glass substrate with a PVA alignment layer at $86{ }^{\circ} \mathrm{C}$; the butylamine was left out of this mixture to prevent main-chain oligomerization. Upon heating from $86{ }^{\circ} \mathrm{C}$ to $104{ }^{\circ} \mathrm{C}$, the location of the reflection band centre didn't change (Fig. S4, ESI $\dagger$ ). When cooling from $86{ }^{\circ} \mathrm{C}$ to $40{ }^{\circ} \mathrm{C}$, the reflection band also did not shift. Based on these findings, it can be concluded that the blue shift upon heating is only present when the oligomer is formed.

To crosslink the polymer film, a photo curing step was carried out with a UV light intensity of $20 \mathrm{~mW} \mathrm{~cm} \mathrm{~cm}^{-2}$ for 10 minutes at $50{ }^{\circ} \mathrm{C}$. After the curing step, the coating was no longer sticky, indicating a solid coating was obtained (Fig. S6A and B, ESI $\dagger$ ). The reflection band became fixed at $800 \mathrm{~nm}$ and no longer shifted with temperature (Fig. 2B and Fig. S6C, ESI $\dagger$ ), being restricted by the high crosslink density of the network. The reflection band was found to be stable at temperatures up to $80{ }^{\circ} \mathrm{C}$, which means that a static IR reflective coating was successfully prepared. The reflection band and transparency to visible light at different viewing angles were also studied. A blue shift of the central wavelength of $165 \mathrm{~nm}$ was observed upon changing the viewing angle from $0^{\circ}$ to $60^{\circ}$ (Fig. S6D, ESI $\dagger$ ).

To further study the temperature response of the oligomer, a series of coatings were prepared by curing the oligomer at $55{ }^{\circ} \mathrm{C}, 45{ }^{\circ} \mathrm{C}, 28{ }^{\circ} \mathrm{C}, 25{ }^{\circ} \mathrm{C}$, and $18{ }^{\circ} \mathrm{C}$, and characterized by wide-angle X-ray scattering (WAXS, Fig. 2C). The measurement showed a diffraction peak located at $q=0.11 \AA^{-1}$, indicating the presence of smectic LC order. The peak at $q=1.25 \AA^{-1}$ represents the side-by-side intermolecular spacing, which is present in both the nematic and smectic LC phases. When the smectic order is present in a nematic or cholesteric phase, this is known as a cybotactic nematic phase. The existence of cybotactic structures over the entire cholesteric temperature range, combined with an increase in peak intensity with decreasing temperature, reveals a gradual pretransitional effect, indicating a gradual change from cholesteric to smectic LC order. ${ }^{20,21,36-40}$

Utilizing the temperature response of the oligomer, coatings with various visible colour patterns were prepared. To adjust the reflection band to the visible region, $2 \mathrm{wt} \%$ more chiral 

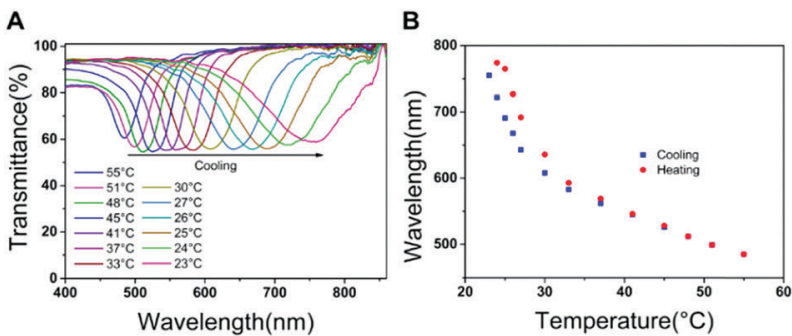

C
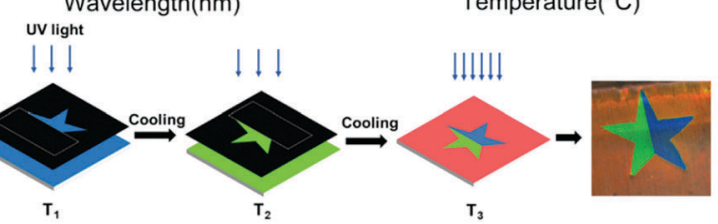

D
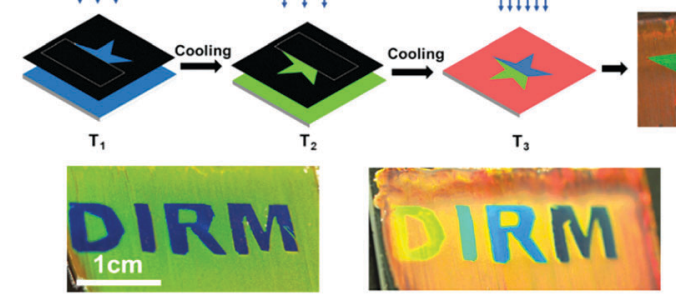

Fig. 3 (A) Reflection band of a coating before crosslinking, with a reflection band in the visible range, measured upon cooling from $55^{\circ} \mathrm{C}$ to $23^{\circ} \mathrm{C}$. (B) Reflection wavelength versus temperature showing both cooling and heating cycles. (C) Schematic representation of the patterning process. (D) Photographs of coatings with 2 or 5 colour 'DIRM' patterns.

dopant $\mathbf{2}$ was added to the oligomer after oligomerization. The shift of the reflection band of this mixture was also studied. Upon cooling from 55 to $23{ }^{\circ} \mathrm{C}$ the reflection band reversibly shifted from $484 \mathrm{~nm}$ to $754 \mathrm{~nm}$, almost covering the entire visible range (Fig. 3A, B and Fig. S7, ESI $\dagger$ ). Then, as shown in Fig. 3C, a paper mask with a star-shaped opening was used to partially expose the coating to UV light. First, the right side of the star was exposed to UV light and cured at $55{ }^{\circ} \mathrm{C}$ with a UV intensity of $0.3 \mathrm{~mW} \mathrm{~cm}^{-2}$ for $15 \mathrm{~s}$, which fixed the reflection band in this area in a blue colour. The lower intensity and shorter exposure time were chosen to prevent unintentional polymerization of the covered areas. The sample was then cooled to $38{ }^{\circ} \mathrm{C}$, causing the unexposed areas to turn green, and the left side of the star was exposed to UV light and cured at $38{ }^{\circ} \mathrm{C}$ with a UV intensity of $0.3 \mathrm{~mW} \mathrm{~cm}{ }^{-2}$ for $15 \mathrm{~s}$, causing this area to be fixed with a green colour. Finally, the coating was cooled to $23{ }^{\circ} \mathrm{C}$, and only the area outside of the star changed to red. The entire sample was then exposed to UV light with an intensity of $2.0 \mathrm{~mW} \mathrm{~cm}^{-2}$ for $10 \mathrm{~min}$ to fix the red colour and to make sure all other areas were properly cured. The final result was a patterned coating with a half green and half blue star on a red background.

Coatings with blue patterns (Star, Heart and DIRM, seen in Fig. S8, ESI $\dagger$ ) which were cured at $55{ }^{\circ} \mathrm{C}$, and a red background which was cured at $23{ }^{\circ} \mathrm{C}$, were also prepared with good resolution using two curing steps in a similar fashion as described above. In addition, a colourful DIRM pattern with a different colour for each letter and a red background was fabricated (Fig. 3D), where the M, R, I, and D were cured at $55,45,39$ and $30{ }^{\circ} \mathrm{C}$, respectively, for $15 \mathrm{~s}$ with an intensity of $0.3 \mathrm{~mW} \mathrm{~cm}{ }^{-2}$, followed by a flood curing at $23{ }^{\circ} \mathrm{C}$ for $10 \mathrm{~min}$ with an intensity of $2 \mathrm{~mW} \mathrm{~cm}^{-2}$, with a good resolution as indicated by Fig. S9 (ESI $\dagger$ ). The stability of the coating after long-term exposure to both heat and UV irradiation was investigated (Fig. S10, ESI $\dagger$ ). Upon long-term heat exposure, the reflection band initially lightly blue-shifted, probably due to some remaining solvent escaping from the material. Upon long-term UV exposure, a reflection band shift was also observed, but the transparency outside the reflection band actually improved. In both cases, the transmittance of the band was hardly affected.

In conclusion, a crosslinkable cholesteric main-chain LC oligomer was successfully prepared and coated on glass, to obtain temperature-responsive reflective coatings that could be patterned by crosslinking different areas at different temperatures. This method requires no complicated chemistry or expensive equipment, and results in stable coatings that can be used for various purposes, such as IR reflective films, anti-counterfeit measures, or aesthetics. Furthermore, the method is flexible, and the properties of the coatings can be easily adjusted by changing the chemical structure of the monomers or the chemicals that are added after oligomerization, or by fine-tuning the degree of polymerization through the stoichiometry, the reaction time and reaction temperature. This versatility of our method can be further exploited to broaden the scope of applications of photonic materials with coloured patterns, while keeping the procedure simple and low cost.

The authors would like to acknowledge colleagues in DIRM and SFD group for inspiring discussions. This work was financially supported by the National Natural Science Foundation of China (No. 51561135014, U1501244), the Program for Changjiang Scholars and Innovative Research Teams in Universities (No. IRT_17R40), Guangdong Innovative Research Team Program (No. 2013C102), Science and technology project of Guangdong Province (No. 2017B020240002), Guangdong Provincial Key Laboratory of Optical Information Materials and Technology (Grant No. 2017B030301007), MOE International Laboratory for Optical Information Technologies, 111 Project, and Top-Notch Graduate Foundation of South China Normal University (No. 2017057). The research of Augustinus Kragt has been funded by the Netherlands Organization of Scientific Research (NWO, 729.001.011).

\section{Conflicts of interest}

There are no conflicts to declare.

\section{Notes and references}

1 S. Vignolini, P. J. Rudall, A. V. Rowland, A. Reed, E. Moyroud, R. B. Faden, J. J. Baumberg, B. J. Glover and U. Steiner, Proc. Natl. Acad. Sci. U. S. A., 2012, 109, 15712-15715.

2 P. Vukusic and J. R. Sambles, Nature, 2003, 424, 852-855.

3 J. Sun, B. Bhushan and J. Tong, RSC Adv., 2013, 3, 14862.

4 L. Bai, Z. Xie, W. Wang, C. Yuan, Y. Zhao, Z. Mu, Q. Zhong and Z. Gu, ACS Nano, 2014, 8, 11094-11100.

5 M. K. Khan, A. Bsoul, K. Walus, W. Y. Hamad and M. J. MacLachlan, Angew. Chem., Int. Ed., 2015, 54, 4304-4308.

6 M. Moirangthem and A. P. H. J. Schenning, ACS Appl. Mater. Interfaces, 2018, 10, 4168-4172. 
7 I. B. Burgess, L. Mishchenko, B. D. Hatton, M. Kolle, M. Lončar and J. Aizenberg, J. Am. Chem. Soc., 2011, 133, 12430-12432.

8 H. S. Lee, J. H. Kim, J.-S. Lee, J. Y. Sim, J. Y. Seo, Y.-K. Oh, S.-M. Yang and S.-H. Kim, Adv. Mater., 2014, 26, 5801-5807.

9 H. S. Lee, T. S. Shim, H. Hwang, S.-M. Yang and S.-H. Kim, Chem. Mater., 2013, 25, 2684-2690.

10 L. He, M. Wang, J. Ge and Y. Yin, Acc. Chem. Res., 2012, 45, 1431-1440.

11 H. Kim, J. Ge, J. Kim, S. Choi, H. Lee, H. Lee, W. Park, Y. Yin and S. Kwon, Nat. Photonics, 2009, 3, 534-540.

12 Y. Kim, M. Wada and N. Tamaoki, J. Mater. Chem. C, 2014, 2, 1921.

13 S.-K. Lee, G.-R. Yi, J. H. Moon, S.-M. Yang and D. J. Pine, Adv. Mater., 2006, 18, 2111-2116.

14 S.-H. Kim, H. S. Park, J. H. Choi, J. W. Shim and S.-M. Yang, Adv. Mater., 2010, 22, 946-950.

15 Z. Xiao, A. Wang, J. Perumal and D.-P. Kim, Adv. Funct. Mater., 2010, 20, 1473-1479.

16 L. Wu, Z. Dong, M. Kuang, Y. Li, F. Li, L. Jiang and Y. Song, Adv. Funct. Mater., 2015, 25, 2237-2242.

17 R. Eelkema and B. L. Feringa, Org. Biomol. Chem., 2006, 4, 3729.

18 T. J. White, M. E. McConney and T. J. Bunning, J. Mater. Chem., 2010, 20, 9832.

19 M. E. McConney, V. P. Tondiglia, J. M. Hurtubise, L. V. Natarajan, T. J. White and T. J. Bunning, Adv. Mater., 2011, 23, 1453-1457.

20 L. V. Natarajan, J. M. Wofford, V. P. Tondiglia, R. L. Sutherland, H. Koerner, R. A. Vaia and T. J. Bunning, J. Appl. Phys., 2008, 103, 93107.

21 F. Zhang and D.-K. Yang, Liq. Cryst., 2002, 29, 1497-1501.

22 N. Tamaoki, Adv. Mater., 2001, 13, 1135-1147.

23 H. Yang, K. Mishima, K. Matsuyama, K. Hayashi, H. Kikuchi and T. Kajiyama, Appl. Phys. Lett., 2003, 82, 2407.
24 J. Geng, C. Dong, L. Zhang, Z. Ma, L. Shi, H. Cao and H. Yang, Appl. Phys. Lett., 2006, 89, 081130.

25 J. Sun, L. Yu, L. Wang, C. Li, Z. Yang, W. He, C. Zhang, L. Zhang, J. Xiao, X. Yuan, F. Lie and H. Yang, J. Mater. Chem. C, 2017, 5, 3678.

26 J. Sun, R. Lan, Y. Gao, M. Wang, W. Zhang, L. Wang, L. Zhang, Z. Yang and H. Yang, Adv. Sci., 2018, 5, 1700613.

27 M. Moirangthem, A. F. Scheers and A. P. H. J. Schenning, Chem. Commun., 2018, 54, 4425-4428.

28 A. J. J. Kragt, D. J. Broer and A. P. H. J. Schenning, Adv. Funct. Mater., 2018, 28, 1704756.

29 W. Zhang, S. Kragt, A. P. H. J. Schenning, L. T. de Haan and G. Zhou, ACS Omega, 2017, 2, 3475-3482.

30 T. H. Ware, M. E. McConney, J. J. Wie, V. P. Tondiglia and T. J. White, Science, 2015, 347, 982-984.

31 T. H. Ware, Z. P. Perry, C. M. Middleton, S. T. Iacono and T. J. White, ACS Macro Lett., 2015, 4, 942-946.

32 M. O. Saed, A. H. Torbati, C. A. Starr, R. Visvanathan, N. A. Clark and C. M. Yakacki, J. Polym. Sci., Part B: Polym. Phys., 2017, 55, 157-168.

33 B. A. Kowalski, T. C. Guin, A. D. Auguste, N. P. Godman and T. J. White, ACS Macro Lett., 2017, 6, 436-441.

34 A. Kotikian, R. L. Truby, J. W. Boley, T. J. White and J. A. Lewis, Adv. Mater., 2018, 30, 1706164.

35 J. E. Stumpel, D. J. Broer, C. W. M. Bastiaansen and A. P. H. J. Schenning, Proc. SPIE, 2014, 9137, 1-7.

36 R. D. Ennulat and J. L. Fergason, Mol. Cryst. Liq. Cryst., 1971, 13, 149-164.

37 J. L. Fergason, N. N. Goldberg and R. J. Nadalin, Mol. Cryst., 1966, 1, 309-323.

38 P. Kassubek and G. Meier, Mol. Cryst., 1969, 8, 305-314.

39 L. Zhang, M. Wang, L. Wang, D. Yang, H. Yu and H. Yang, Liq. Cryst., 2016, 43, 750.

40 F. Wang, H. Cao, K. Li, P. Song, X. Wu and H. Yang, Colloids Surf., A, 2010, 410, 31. 